\title{
IMPROVING THE SEVENTH GRADE STUDENTS' VOCABULARY MASTERY THROUGH WORD SEARCH PUZZLE AT SMP TRISAKTI 1 MEDAN
}

\author{
Edinopa Pandiangan, Novalina Sembiring, Jontra J. Pangaribuan \\ Catholic University of Saint Thomas
}

\begin{abstract}
Vocabulary is one of components in the language learning because it is the basic for the people to speak the language. Therefore this study was conducted to improve students' vocabulary mastery by applying Word Search Puzzle. This research design is classroom action research. The subjects of this research were the seventh grade of SMP Trisakti 1 Medan. The result showed in cycle I, there were 5 students $(15,63 \%)$ whose vocabulary scores had achieved that the target of indicator with mean score is 52,89 (KKM 70) and there were 27 students $(78,13 \%$ ) whose scores were still far from the target. As there were 27 students whose scores below the target, so the indicator of the research had not been fulfilled yet in the first cycle. Nevertheless, in order to fulfill the indicator which is $75 \%$ student must be able to get score 70 or more, so the next cycle was conducted. From data in cycle II, there were only 5 students $(22 \%)$ whose scores were still far from target. In other hand, total students who could get the target are 27 students $(78 \%)$ with mean score 87,10. Moreover, there is significant improvement from pretest and post-test. It means that they were good enough in vocabulary after being taught through Word Search Puzzle. The result of this resesarch also shows that students' response after being taught through Word Search Puzzle is good. It can be stated that Word Search Puzzle can improve the students' vocabulary mastery at SMP Trisakti 1 Medan.
\end{abstract}

Keywords: vocabulary mastery, word search puzzle, classroom action research

\section{INTRODUCTION}

Vocabulary is very important for every student who wants to master English. Without vocabulary, students will find difficulty to master English. Richard and Renandya (2002: 255) say that vocabulary is core component of language proficiency and provides much basis for how well the students speak, listen, read, and write. Therefore, vocabulary is an important basis to learn English. Students cannot read, speak, listen, and write without understanding the meaning of words. Teaching vocabulary will make the students to master the reading, speaking, listening and writing skill easily.

Many students find difficulty to enrich their vocabulary or to memorize new words given by teacher. It is something normal for the students because English is not their mother tongue. In this case, teacher needs to find out the interesting way in teaching the material to make students understand and remember new words easily. Students are easily bored when they do not understand the materials that are taught by the teacher. To overcome this problem, the teacher must be more creative in the teaching learning process.

In Junior High School level, English is not something new for students. They have known English since they were in the kindergarten or elementary school. However, students are still difficult to remember the new words. This situation also happened during the writer's Internship Program at SMP Trisakti 1 Medan. Students easily forgot the new words given by teacher and not enthusiastic in learning vocabulary since they had to memorize a lot of words by themselves.

Using games is one alternative that can be used to improve student's vocabulary mastery. Word Search Puzzle is a kind of games. The writer chooses word search puzzle to

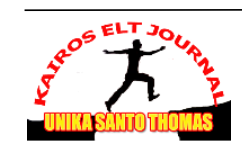


help teachers improving students' vocabulary mastery. Using word search puzzle during teaching will make the students be active learners. Besides, it can make the students be independent because they are asked to be discipline with their task and understanding the material deeper. In that way, word search puzzle offers an excitement for students in learning English for fun.

This research is important to conduct in order to help the teachers in solving students' problem in memorizing new words. By conducting this research, teacher will get solution in teaching vocabulary. In that way, teacher will not use monotonous strategy in teaching and learning process which makes the students feel bored. In addition, students will not feel difficult or afraid in memorizing vocabulary because they do it excitingly and enthusiastically.

From the explanation, word search puzzle is a good alternative in teaching English. There were some previous researches regarding Word Search Puzzle. The first research was conducted by Utami (2014) entitled "Improving Students' Vocabulary Mastery Using Crossword Puzzles for Grade VII of SMP Srandakan in the Academic Year of 2013/2014”. It showed that the mean of pre-test was 53, 8 the mean of post-test, was 68,3 . In other words, the result of the study indicates that Word Search Puzzle was effective not only to help students improving their vocabulary, but also to help the students building their mental abilities to share knowledge to their friends and take responsibility of their group. The second one was conducted Permatasari (2015) entitled "Improving the Eighth Grade Students' Vocabulary Achievement by Using Crossword Puzzles at MTsN Arjasa Jember". It showed that the mean pre-test was 66,7 the mean of post-test was 76,7 . Then she said that the students who were taught by using Word Search Puzzle technique felt more interesting and fun, and the students were not bored in the classroom during the process of teaching learning. The students became more active in the class.

Based on the background of the study, the writer is interested in conducting a research entitled "Improving the Seventh Grade Students' Vocabulary Mastery Through Word Search Puzzle at SMP Trisakti 1 Medan”. The writer chooses SMP Trisakti 1 Medan as the location of research because based on the preliminary observation done by the writer, it is needed to improve the students' vocabulary mastery by applying Word Search Puzzle and there are no similar studies which have been conducted at the school.

\section{REVIEW OF LITERATURE Vocabulary}

Vocabulary is a component of English. Without vocabulary mastery it is impossible to make meaningful sentences in communication. Vocabulary is a list of words. Kamil and Hiebert (2005:3) state that vocabulary is the knowledge of meanings of words. It means vocabulary is all about words, the words in a language or a special set of words people are trying to learn. The term vocabulary refers to students' understanding of oral and print word. Vocabularies include conceptual knowledge of words that go well beyond a simple dictionary definition. Students' vocabulary knowledge is a building process that occurs over time as they make connection to others words; learn examples and non examples of the word and related words, and the use of words accurately within the context of the sentence.

Vocabulary is an obvious area for language variation. Celce-Murcia \& Ohlstain (2000:78) state that the vocabulary is a key of language, because without vocabulary the language cannot be conveyed. Language skills like speaking, writing, reading, and listening will not be able to be conveyed to the other people if we do not know the meaning of the words to be spoken or written. In reading and writing, we cannot read and write if we do not know words or the meaning of the words to be read or write. 
KAIROS ELT JOURNAL, Vol. 2, No. 1, April 2018

Copyright@2018, ISSN: 2580-4278

\section{Kinds of Vocabulary}

Some experts divide vocabulary into some types. Hatch and Brown (1995:1) indicate two kinds of vocabulary, namely receptive vocabulary and productive vocabulary.

\section{a. Receptive Vocabulary}

Receptive vocabulary is words that learners recognize and understand when they are used in context, but which they cannot produce. It is vocabulary that learners recognize when they see or meet in reading text but do not use it in speaking and writing.

\section{b. Productive Vocabulary}

Productive vocabulary is the words that the learners understand and can pronounce correct and use constructively in speaking and writing. It involves what is needed for receptive vocabulary plus the ability to speak or write at the appropriate time. Therefore, productive vocabulary can be addressed as an active process, because the learners can produce the words to express their thoughts to others.

Harmer (1991:159) states that there are two kinds of vocabulary; they are active vocabulary and passive vocabulary.

1) Active vocabulary is used in oral and written expression by the students. The words that the students understand well enough they use the words effectively in both speaking and writing.

2) Passive vocabulary is deals with words the students will recognize understand in a context that helps them recall the world meaning. The students usually apply passive vocabulary and learning materials.

In relation with to the teaching language skills, vocabulary is divided into four parts, they are reading vocabulary, listening vocabulary, writing vocabulary, and speaking vocabulary. Reading vocabulary is all the words that readers can recognize when reading. This is the largest type of vocabulary simply because it includes the other three. Listening vocabulary is all the words that the listeners can recognize when listening speech. This vocabulary is aided in size by context and tone of voice. Writing vocabulary is all the words that the writers can employ in writing. Contrary to the previous types of vocabulary, the writing vocabulary is stimulated by its user. Speaking vocabulary is all the words that the speakers can use in speech.

\section{Teaching and Learning Vocabulary}

Teaching is the way of convey information to someone. Teacher needs creativity to improve his vocabulary teaching. According to Vacca (1999: 316), teaching vocabulary often as means of assigning a corpus of words rather than exploring words meaning and relationship that contribute to students' conceptual awareness and understanding of a subject.

Teaching is an interactive process between the teacher and students and among students themselves. The students need to comprehend the new language, and the teacher needs creativity to improve his or her teaching vocabulary. Vocabulary, in addition to grammar and pronunciation, is one of language elements considered necessary for language mastery. Vocabulary teaching aims at enabling learners to understand the concepts of unfamiliar words, gain a greater number of words, and use words successfully for communicative purpose. Thus, good vocabulary mastery supports mastery of each of language skills, both receptive (listening and reading) and productive (speaking and writing).Moreover, the good way of teaching and learning will produce in vocabulary acquisition of students.

Heinich (1996:16) also states that there are several categories of methods in teaching English vocabulary. They are elaborated as follows:

1) Presentation

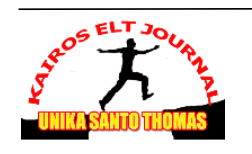


In the presentation method, a source tells, dramatizes, or otherwise discarnate in information to learners. It is one way communication by the source with no immediate response.

2) Demonstration

In this method of instruction, learners view a real or lifelike. Demonstration maybe recorded and played back by means of media such as video.

3) Discussion

As a method, discussion involves the exchange of ideas and opinions among students or among students and teacher. It can be used in small or large groups.

4) Drill and practice

In drill and practice, learners are led through a series of practices exercises designed to increase fluency in a new skill or to refresh an existing one. To be effective, the drill and practice exercises should include feed-back to reinforce correct response and remediate errors learners might take along the way.

5) Tutorial

Tutorial is most often done one on one and is frequently used to teach basic skills, such as reading and arithmetic.

6) Cooperative Learning

Critics of competitive learning urge instead an emphasis on cooperative learning as an instructional technique. They argue that learners need to develop skills in working and learning together because their eventual workplaces will require teamwork.

7) Gaming

Gaming provides a playful environment in which learners follow prescribed rules as they strive to attain a challenging goal. Games can be a way for students to be active learners.

8) Stimulation

Stimulation involved learners confronting a scaled-down version of real-life situation. The stimulation may involve participant dialog, manipulation of materials and equipment, or interaction with a computer.

9) Discovery

The discovery technique uses an inductive or inquiry approach learning, it presents problems to be solved through trial and error.

10) Problem solving

Giving a problem to solve can provide the starting point for learning. The students can acquire the knowledge and skills needed in the teaching and learning process.

From the statements above there are some techniques in teaching vocabulary, such as game, practice and drill, discussion etc. each technique has strength and a weakness. Firmly, the teacher must choose the suitable technique that is similar to the students' characteristics.

\section{Games}

Game is an agreeable way of getting a class to use its initiative in English. Game is usually related with competition to win, rules the follow, and enjoyment to experience. Through game students can learn in a relax atmosphere.

According to Allen (1983:52) game is helpful because they can make students feel that certain words are important and necessary. Without those words, the object of the game cannot be achieved. Automatically, game can bring the way of thinking about material in process learning. Game is the activity which is done through certain role. This role has clear goals and activity. That is why, using game to teach students vocabulary is suggested because games will help the students relaxing and enjoy learning atmosphere.

Based on the above definition, game is a part of learning process. Game is called as effective learning process. The teacher can easily keep control of the class while students enjoy

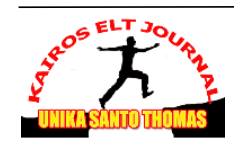


and follow the logic of the game and play it correctly, achieving at the same time the goals of the activity effectively.

\section{Word Search Puzzle}

Word search puzzle is one of games which are used by the teacher in his learning goal. It is used to make students easier in absorbing material in their learning process. Relating to the importance of teaching vocabulary through Word Search Puzzle, as far as it is know some students are always confused with their problem of through puzzle. Teaching vocabulary by using Word Search Puzzle make students more relax, enjoy, happy and understanding about the material.

Word search puzzle is one of many instructional games that reinforce word level into a grid and persuades the class to make suggestions for the puzzle clues. According to Richard and Rodgers (1986: 6) Word Search Puzzle is a word game that is should be practice in meaningful context and in sentences and should be isolated. This game is good to review general vocabulary, without ever tiring the students. A word search puzzle is a word game that is letters of a word in a grid that usually has a rectangular or square shape. Many word search games have a theme to which all the hidden words are related. Word Search puzzle is a popular game that has sets of grids to be filled with words. Based on the definitions above, puzzle has become one of alternative games in teaching- learning process. The puzzle itself is easy to play, so that it can be used to practice in the classroom in order to develop students' communication skill, especially students' vocabulary.

This game can help the teacher to teaching the students understanding about last materials or as a post-test. The students will feel enjoy to do it, but the teacher will be able to apply all material based on the learning goal.

Table 1. The example of Word Search Puzzle.

\begin{tabular}{|l|l|l|l|l|l|l|l|l|l|}
\hline $\mathbf{K}$ & $\mathbf{E}$ & $\mathbf{O}$ & $\mathbf{K}$ & $\mathbf{H}$ & $\mathbf{L}$ & $\mathbf{J}$ & $\mathbf{D}$ & $\mathbf{H}$ & $\mathbf{I}$ \\
\hline $\mathbf{A}$ & $\mathbf{Z}$ & $\mathbf{G}$ & $\mathbf{Q}$ & $\mathbf{A}$ & $\mathbf{I}$ & $\mathbf{D}$ & $\mathbf{O}$ & $\mathbf{G}$ & $\mathbf{K}$ \\
\hline $\mathbf{N}$ & $\mathbf{X}$ & $\mathbf{L}$ & $\mathbf{E}$ & $\mathbf{O}$ & $\mathbf{Y}$ & $\mathbf{I}$ & $\mathbf{F}$ & $\mathbf{R}$ & $\mathbf{J}$ \\
\hline $\mathbf{G}$ & $\mathbf{C}$ & $\mathbf{I}$ & $\mathbf{R}$ & $\mathbf{O}$ & $\mathbf{E}$ & $\mathbf{U}$ & $\mathbf{G}$ & $\mathbf{E}$ & $\mathbf{G}$ \\
\hline $\mathbf{A}$ & $\mathbf{O}$ & $\mathbf{O}$ & $\mathbf{T}$ & $\mathbf{J}$ & $\mathbf{A}$ & $\mathbf{E}$ & $\mathbf{A}$ & $\mathbf{D}$ & $\mathbf{N}$ \\
\hline $\mathbf{R}$ & $\mathbf{U}$ & $\mathbf{N}$ & $\mathbf{O}$ & $\mathbf{L}$ & $\mathbf{A}$ & $\mathbf{M}$ & $\mathbf{B}$ & $\mathbf{O}$ & $\mathbf{M}$ \\
\hline $\mathbf{O}$ & $\mathbf{T}$ & $\mathbf{P}$ & $\mathbf{J}$ & $\mathbf{H}$ & $\mathbf{T}$ & $\mathbf{T}$ & $\mathbf{S}$ & $\mathbf{A}$ & $\mathbf{V}$ \\
\hline $\mathbf{O}$ & $\mathbf{U}$ & $\mathbf{I}$ & $\mathbf{K}$ & $\mathbf{A}$ & $\mathbf{G}$ & $\mathbf{G}$ & $\mathbf{A}$ & $\mathbf{L}$ & $\mathbf{O}$ \\
\hline $\mathbf{P}$ & $\mathbf{Y}$ & $\mathbf{U}$ & $\mathbf{A}$ & $\mathbf{A}$ & $\mathbf{K}$ & $\mathbf{D}$ & $\mathbf{T}$ & $\mathbf{H}$ & $\mathbf{E}$ \\
\hline $\mathbf{O}$ & $\mathbf{E}$ & $\mathbf{Y}$ & $\mathbf{S}$ & $\mathbf{S}$ & $\mathbf{M}$ & $\mathbf{S}$ & $\mathbf{Y}$ & $\mathbf{M}$ & $\mathbf{Y}$ \\
\hline $\mathbf{L}$ & $\mathbf{I}$ & $\mathbf{I}$ & $\mathbf{P}$ & $\mathbf{O}$ & $\mathbf{L}$ & $\mathbf{K}$ & $\mathbf{J}$ & $\mathbf{H}$ & $\mathbf{I}$ \\
\hline
\end{tabular}

Key Answer

1. lamb

2. kangaroo

3. lion

4. $\operatorname{dog}$

\section{The Advantages of Word Search Puzzle}

Rosi (2015: 12) states that the advantages of puzzle can be an inspiration sources for teachers who do not have certain ideas, and will make it easier for teachers to explain materials

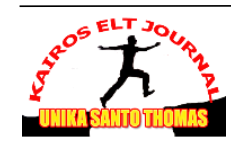


to students in the class. Word Search Puzzle can help to reinforce spellings in your student's mind, particularly in the case of puzzle, where it is crucial to spell linked words correctly to be able to complete the task. Word Search Puzzle is really goods improving student's processing speed, so they are able to arrive at the correct answer faster. Word search puzzle technique has many advantages in improving vocabulary mastery. These advantages are not only for teachers but also for students.

1. For teachers, this game can help them to explain more about material. In addition, the teacher will know how far the material is understood by the student.

2. For students, this game will make them get deeper understanding about material learned in the class.

\section{RESEARCH METHOD}

This research is an Action Research. Since it is typically collaborative action research, the writer will work together with collaborator that is the English teacher of students of grade VII C at SMP Tisakti 1 Medan. The writer and the collaborator will work together during the time in conducting the research. The research designs are both quantitative and qualitative research and completed by a Classroom Action Research (CAR). According to Husni (2015: 75) action research is to solve the problem and make improvement of the teacher learning process in the classroom. In addition, Burns (1999: 162) the most effective outcome would involve not only a resolution of the problems but also reframing of the problem in such a way that it would lead new questions. In this research, the outcome validity is ensured by analyzing the students' development during the teaching- learning process based on the indicators of the lesson had been formulated. It is elaborate on the lesson plans.

Quantitative research is used to quantify the problem by way generating numerical data or data can be transformed into useable statistic. Quantitative Data use measurable data formula facts and uncover pattern in research. Qualitative research is also used to uncover trends in thought and options, and dive deeper into the problem .Qualitative data are obtained from test, observation sheets field notes and questionnaire. Quantitative data are obtained from students' pre-test and post-test.

The research will be conducted in SMP Trisakti 1 Medan which is located at Jl. H. M. Joni No.52 Medan. There are two reasons why the writer chooses the school as the location of the research. Firstly, based on the writer's experience during intensive in that school, it is needed to improve vocabulary mastery of the Seventh Grade Students of SMP Trisakti 1 Medan. Secondly, based on the writer's knowledge there has never been any research about improving students' vocabulary mastery by using word search puzzle. This research will be conducted in August and September 2018.

The subject of the study is the seventh grade students of SMP Trisakti 1 Medan the Academic Year 2018/2019. There are four classes of the seventh grade students which consist of class A, B, C, D. The writer chooses class VII-C as the subject of this study which consists of 32 students.

The research will be conducted in SMP Trisakti 1 Medan which is located at Jl. H. M. Joni No.52 Medan. There are two reasons why the writer chooses the school as the location of the research. Firstly, based on the writer's experience during intensive in that school, it is needed to improve vocabulary mastery of the Seventh Grade Students of SMP Trisakti 1 Medan. Secondly, based on the writer's knowledge there has never been any research about improving students' vocabulary mastery by using word search puzzle. This research will be conducted in August and September 2018. 
The subject of the study is the seventh grade students of SMP Trisakti 1 Medan the Academic Year 2018/2019. There are four classes of the seventh grade students which consist of class A, B, C, D. The writer chooses class VII-C as the subject of this study which consists of 32 students.

\section{DATA ANALYSIS \\ Data Analysis}

The data in this study were collected by quantitative and qualitative technique. The quantitative data were taken from the students' scores which were obtained from pre-test, formative test in cycle I and post-test in cycle II. Every cycle was conducted in four meetings. Pre-test was given in the first meeting and formative test was given and the end of cycle I in the last meeting, and post-test was given at the end of cycle II in the last meeting. The qualitative data were taken from observation sheets, field notes and questionnaire which describe an event that occurred when conducting this study. The qualitative data analysis showed that the process of improving students' vocabulary mastery through Word Search Puzzle ran well.

\section{The Quantitative data}

The quantitative data were taken from the test result of pre-test, formative test and posttest. Before conducting the treatment, the pre-test was given to measure how far the students' vocabulary mastery. In the last meeting of cycle I, the formative test was given measure the improvement of the students. Then, the post-test was given to the students at the end of the whole cycles to measure the students' improvement after the treatment. The result of the students' score in every test can be seen from the table and histogram of score interval and the frequency as follows:

\section{Table 2. Pre-Test Score Interval}

\begin{tabular}{|l|l|l|}
\hline Score Interval & Frequency & Percentage \\
\hline $20-29$ & 3 & $9,375 \%$ \\
\hline $30-39$ & 5 & $15,625 \%$ \\
\hline $40-49$ & 4 & $12,5 \%$ \\
\hline $50-59$ & 8 & $25 \%$ \\
\hline $60-69$ & 7 & $21,875 \%$ \\
\hline $70-79$ & 4 & $12,5 \%$ \\
\hline $80-89$ & 1 & $3,125 \%$ \\
\hline Total & $\mathbf{3 2}$ & $\mathbf{1 0 0 \%}$ \\
\hline
\end{tabular}

Scoring Interval is found by applying this following formula:

Scoring Interval $(\mathrm{P})=\frac{X n-X 1}{1+\log n}$

Where:

- The division of distance $(\mathrm{R})=\mathrm{Xn}$ (the highest score) $-\mathrm{X} 1$ (the lowest score) in which, Xn $=80$ and $\mathrm{X} 1=20$

- The sum of whole data $(K)=1=3,3 \log n$,

- $\mathrm{N}=$ the number of data, $\log _{32}=1,50$

- So, $\mathrm{P}=\frac{80-20}{1+3,3 \log 32}=\frac{60}{1+4,97}=\frac{60}{5,97}=10$

From the table of pre-test score interval and frequency above, the writer presented the data in histogram. 
KAIROS ELT JOURNAL, Vol. 2, No. 1, April 2018

\section{Copyright $\odot 2018$, ISSN: 2580-4278}

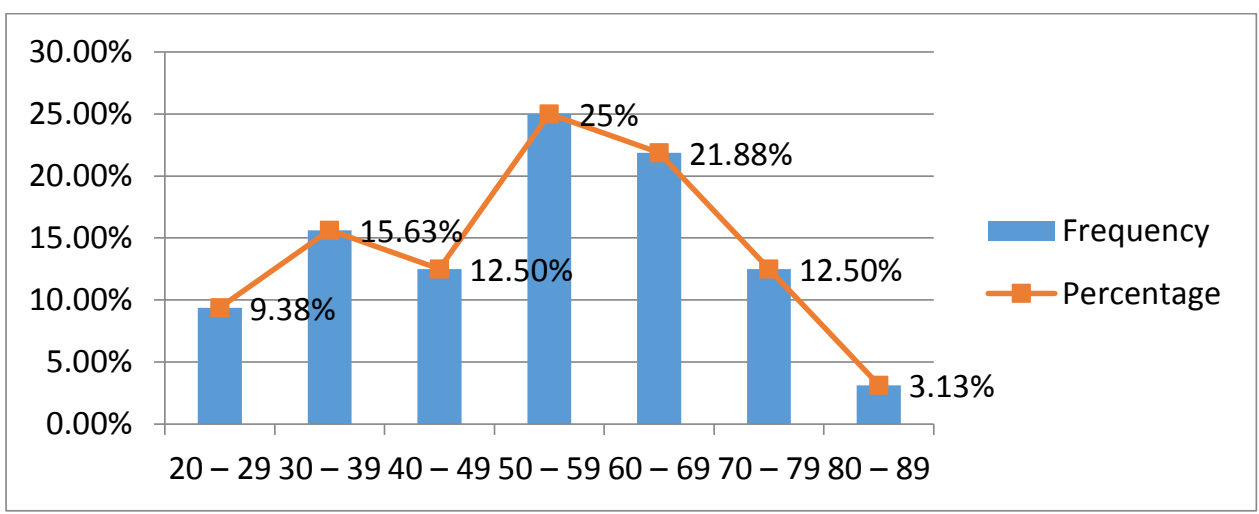

Figure 1. The Histogram of Pre-Test Score

From the histogram of pre-test, the highest frequency interval is 50 to 59 with 8 students. The lowest frequency intervals are 80 to 89 , there is $1(3,13 \%)$ student who got pretest score in interval. In addition, there are $3(9,375 \%)$ students who got score in each interval 20 to 29 . Then, there are $5(15,625 \%)$ students who got score in each interval 30 to 39 . There are $4(12,5 \%)$ students who got score in interval 40 to 49 and 70 to 79 . Then, there are 7 $(21,875 \%)$ students who got score in interval 60 to 69 .

Table 3. Formative Test Score Interval

\begin{tabular}{|l|l|l|}
\hline Score Interval & Frequency & Percentage \\
\hline $37-45$ & 1 & $3,125 \%$ \\
\hline $46-54$ & 0 & $0 \%$ \\
\hline $55-63$ & 0 & $0 \%$ \\
\hline $64-72$ & 0 & $0 \%$ \\
\hline $73-81$ & 10 & $31,25 \%$ \\
\hline $82-90$ & 21 & \multicolumn{1}{|c|}{$65,625 \%$} \\
\hline Total & & $\mathbf{1 0 0 \%}$ \\
\hline
\end{tabular}

Scoring Interval is found by applying this following formula:

Scoring Interval $(\mathrm{P})=\frac{X n-X 1}{1+3,3 \log n}$

Where:

The division of distance $(\mathrm{R})=\mathrm{Xn}$ (the highest score) $-\mathrm{X} 1$ (the lowest score) in which, $\mathrm{Xn}=90$ and $\mathrm{X} 1=37$

- The sun of whole data $(K)=1+3,3 \log n$,

- $\mathrm{N}=$ the number of data, $\log _{32}=1,50$

- So, $\mathrm{P}=\frac{90-37}{1+3,3 \log 32}=\frac{53}{1+4,97}=\frac{53}{5,97}=9$

From the table of formative test score interval and frequency above, the writer presented the data in histogram. 
KAIROS ELT JOURNAL, Vol. 2, No. 1, April 2018

Copyright $\odot 2018$, ISSN: 2580-4278

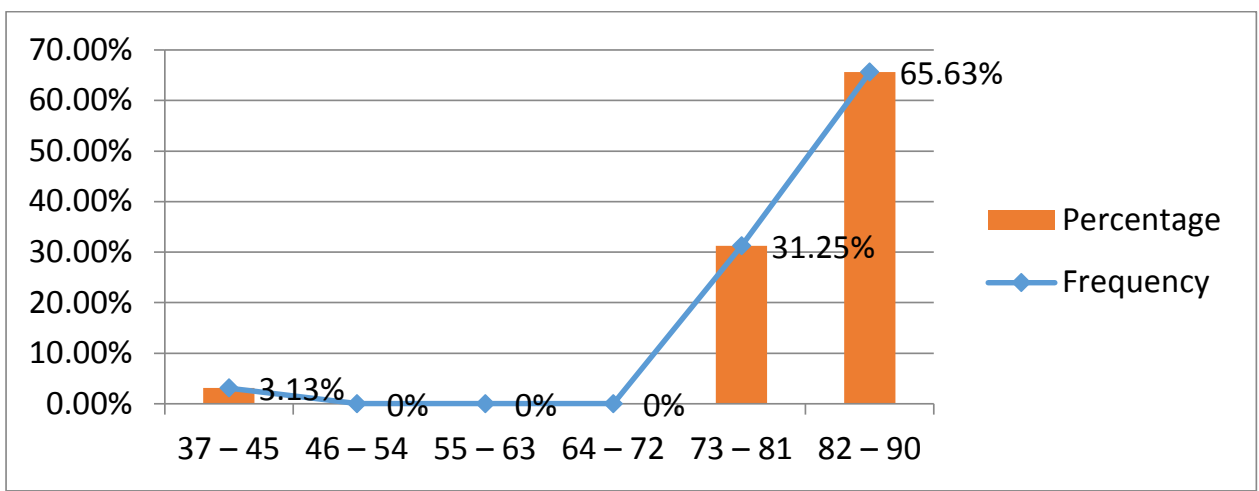

Figure 2. The Histogram of Formative Test Score

From the histogram of formative test, the highest frequency interval is 82 to 90 $(65,63 \%)$. It means that there are 21 students got the highest frequency in interval 82 to 90 . The lowest frequency intervals are 46 to 54,55 to 63 and 64 to 72 there is no student who got formative test score in this interval. In addition, in the formative test there are $1(3,13 \%)$ student who got score in interval 37 to 45 . Then, there are $10(6,25 \%)$ students who got score in interval 73 to 81 .

Table 4. Post - Test Score Interval

\begin{tabular}{|l|l|l|}
\hline Score Interval & Frequency & Percentage \\
\hline $37-46$ & 1 & $3,125 \%$ \\
\hline $47-56$ & 0 & $0 \%$ \\
\hline $57-66$ & 2 & $6,25 \%$ \\
\hline $67-86$ & 10 & $31,25 \%$ \\
\hline $87-96$ & 5 & $15,625 \%$ \\
\hline $97-100$ & 14 & $43,75 \%$ \\
\hline Total & $\mathbf{3 2}$ & $\mathbf{1 0 0 \%}$ \\
\hline
\end{tabular}

Scoring Interval is found by applying this following formula:

Scoring interval $(\mathrm{P})=\frac{X n-X 1}{1+3,3 \log n}$

Where:

- The division of distance $(\mathrm{R})=\mathrm{Xn}$ (the highest score) $-\mathrm{X} 1$ (the lowest score) in which, $\mathrm{Xn}=100$ and $\mathrm{X} 1=37$

- The sun of whole data $(K)=1+\log n$,

- $\mathrm{N}=$ the number of data, $\log _{32}=1,50$

- So, $\mathrm{P}=\frac{100-37}{1+3,3 \log 32}=\frac{63}{1+4,97}=\frac{63}{5,97}=10$

From the table of post-test score interval and frequency above, the writer presented the data in histogram. 
KAIROS ELT JOURNAL, Vol. 2, No. 1, April 2018

Copyright $\odot 2018$, ISSN: 2580-4278

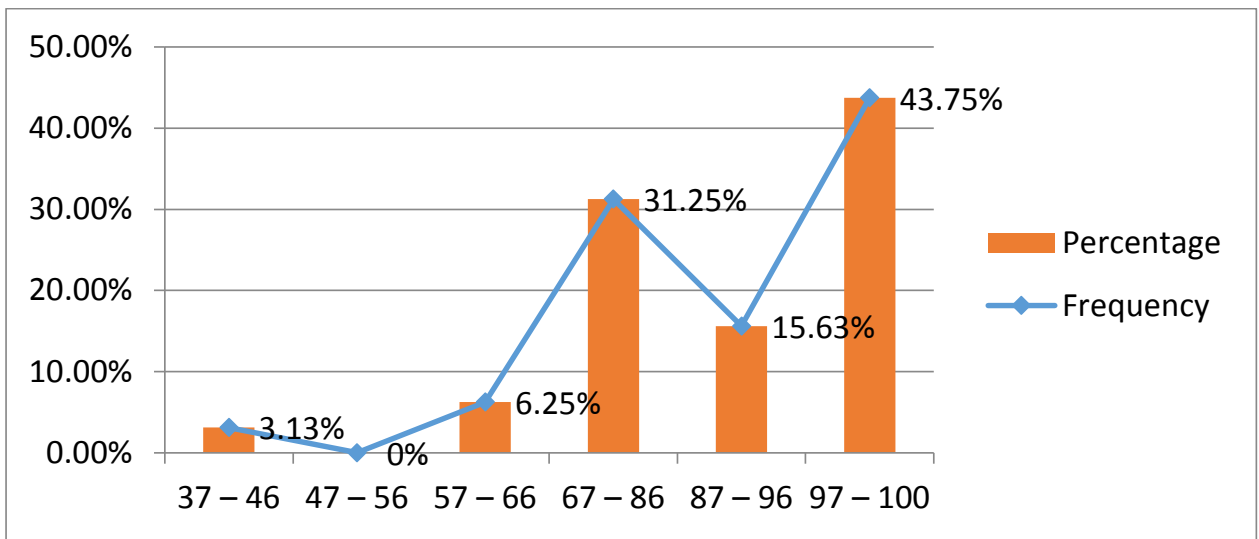

\section{Figure 3. The Histogram of Post-Test Score}

From the histogram of post-test, the highest frequency intervals are 97 to $100(43,75 \%)$. It means that there are 14 students got the highest frequency in interval 97 to 100 . The lowest frequency are 47 to 56 . It means thats there is no students who got post-test score in this interval. In addition, there are $1(3,13 \%)$ students who got score in interval 37 to 46 . Then there are $2(6,25 \%)$ students who got score in interval 57 to 66 . Then, there are $5(15,63)$ students who got score in interval 87 to 96 . There are $10(31,25 \%)$ students who got score in this interval 67 to 86 .

To found the students mean score in each test, the writer applied the following formula:

$\overline{\mathrm{X}}=\frac{\sum \mathrm{X}}{N}$

From the formula above, the result of the students'mean score could be seen as follows:

a. In pre-test total score of the students is $\frac{1692}{32}=52,89$

b. In formative test, the total score of the students is $\frac{2.618}{32}=81,81$

c. In post-test the total score of the students is $\frac{2.787}{32}=87,10$

Finally, from the result of the tables and charts of pre-test, formative test, and post-test, the writer presented the conclusions if the quantitative data as follows:

Table 5. Quantitative Data

\begin{tabular}{|l|l|l|l|}
\hline Components & Pre-test & Formative & Post-test \\
\hline Mean & $\mathbf{5 2 , 8 9}$ & $\mathbf{8 1 , 8 1}$ & $\mathbf{8 7 , 1 0}$ \\
\hline Median & $\mathbf{5 7 , 7 5}$ & $\mathbf{8 3 , 3}$ & $\mathbf{9 5}$ \\
\hline Mode & $\mathbf{5 7 , 7 5}$ & $\mathbf{8 6 , 6}$ & $\mathbf{1 0 0}$ \\
\hline
\end{tabular}

To find out the percentage of the students' improvement score from thenpre-test to posttest, the writer applied the following formula:

$\mathrm{P}=\frac{y 1-y}{y} x 100 \%$

$\mathrm{P}=\frac{87,10-52,89}{52,89} x 100 \%$

$\mathrm{P}=\frac{34}{52,89} x 100 \%$

$\mathrm{P}=64,28$

Thus, the percentage of the students' improve score from the pre-test to post-test is $64.28 \%$ and from the pre-test to formative test is $54,83 \%$. The calculation of percentage of students' improvement score was attached appendix 2 . From the table of quantitative data, the writer presented the quantitative data in the following chart. 
KAIROS ELT JOURNAL, Vol. 2, No. 1, April 2018

Copyright@2018, ISSN: 2580-4278

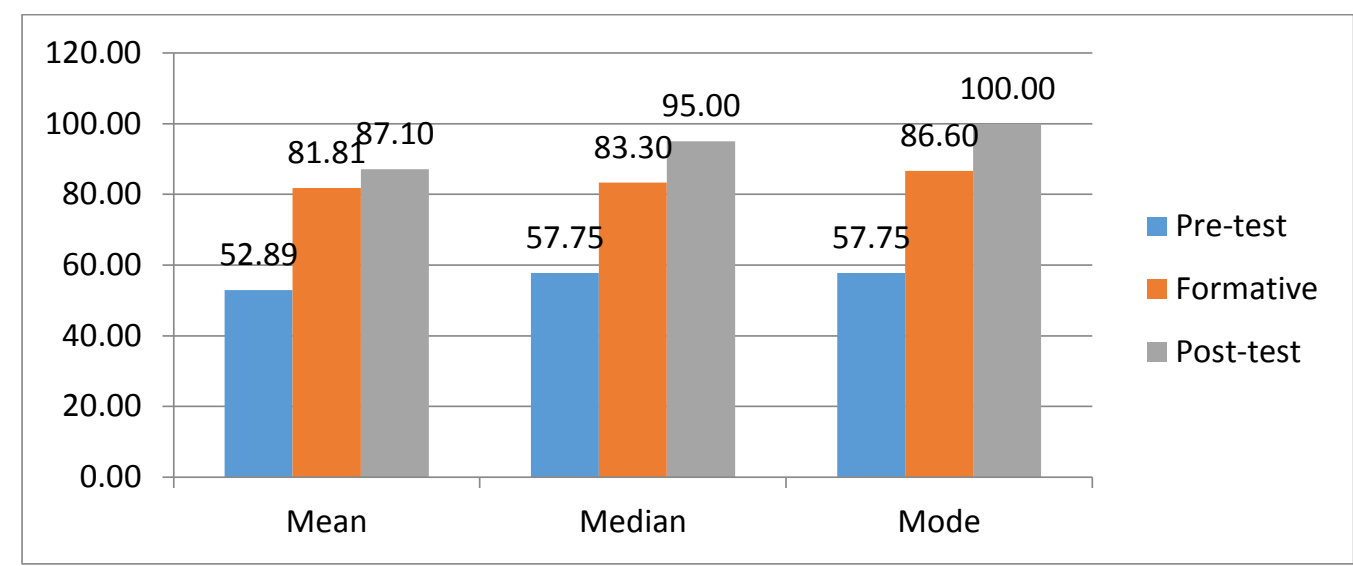

Figure 4. The Histogram of Quantitative Data

From the result of the students' score, it is concluded that the students' mean score is increased. It could be seen from the mean score in pre-test, formative test, and post-test. In pretest, the students' mean score is 52.89. while the students' mean score in the formative test is 81.81 and in the post-test is 87.10 . Then the mode and median of the students' score in posttest are higher than pre-test. It means that there is development of the students' vocabulary mastery through Word Search Puzzle.

The percentage of the students' vocabulary mastery was presented as follows:

Table 6. Percentage of Students' Achievement Who Got Score $\geq 70$

\begin{tabular}{|l|l|l|}
\hline Components & Students Who Got Score $\geq 70$ & Percentage \\
\hline Pre-test & $\mathbf{5}$ & $\mathbf{1 5 , 6 3 \%}$ \\
\hline Formative Test & $\mathbf{3 1}$ & $\mathbf{9 6 , 8 7} \%$ \\
\hline Post-test & $\mathbf{2 7}$ & $\mathbf{7 8 , 1 3} \%$ \\
\hline
\end{tabular}

To find out the percentage of the students who passed the Mastery Minimum Criteria (Kriteria Ketuntasan Minimal (KKM) ) in the pre-test, formative test and post-test, the writer applied the following formula:

$\mathrm{P}=\frac{R}{T} \times 100 \%$

From the formula above, the results of the students' percentage score could be seeenas follows:

a. In the pre-test, the total number of the students who passed the KKM is $\frac{5}{32} x 100 \%=15,63 \%$

b. In the formative test, the total number of the students who passed the KKM is $\frac{31}{32} \times 100 \%=96,87 \%$

c. In the post-test, the total number of the stiudents who passed the KKM is $\frac{27}{32} \times 100 \%=78,13 \%$

From the percentage of students' achievement, the writer presented the data in histogram. 
KAIROS ELT JOURNAL, Vol. 2, No. 1, April 2018

Copyright@2018, ISSN: 2580-4278

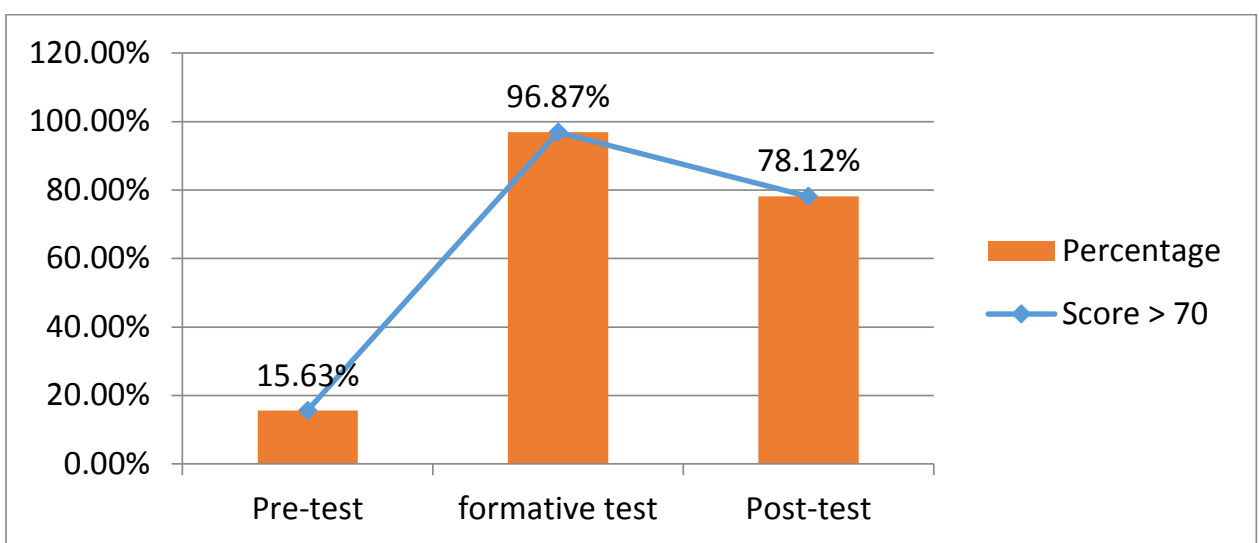

Figura 5. The Histogram of the Percentage Students' Achievement Who Got Score $\geq 70$

In the pre-test, there are 5 students $(15,63 \%)$ who got score $\geq 70$ and in formative test there are 31 students $(96,87 \%)$ who got score $\geq 70$, meanwhile, in the post-test there are 27 students $(78,13 \%)$ who got score $\geq 70$. From the pre-test to post-test, there is significant development of students' vocabulary mastery from $15,63 \%$ to $78,13 \%$. It is concluded that Word Search Puzzle can help students improve their vocabulary mastery.

\section{The Qualitative Data}

The qualitative data were taken from observation sheets, field notes, and questionnaire and were presented below.

\section{Observation Sheet}

Observation sheet was focused on the situation of teaching learning process including the students' activities, behavior and interaction in the classroom. The observation sheet was made by the writer and it checked by the techer who acted as the collaborator and observed the teaching leraning process in the cycle 1 and cycle 2 . The complete data can be seen as follows:

Table 7. Observation Sheet I Cycle I and II

\begin{tabular}{|l|l|l|l|l|l|}
\hline \multirow{2}{*}{ No. } & Word Search Puzzle & \multicolumn{2}{l|}{ Cycle I } & \multicolumn{2}{l|}{ Cycle II } \\
\cline { 2 - 6 } & & Yes & No & Yes & No \\
\hline 1. & $\begin{array}{l}\text { Does the teacher create and } \\
\text { implement a set of rules? }\end{array}$ & $\sqrt{ }$ & & $\sqrt{ }$ & \\
\hline $2 .$. & $\begin{array}{l}\text { Do the students understaf what they } \\
\text { are thought? }\end{array}$ & $\sqrt{ }$ & & $\sqrt{ }$ & \\
\hline 3. & Does the teacher give an example? & $\sqrt{ }$ & & $\sqrt{ }$ & \\
\hline 4. & $\begin{array}{l}\text { Does the teacher explain relevant } \\
\text { materials and skill? }\end{array}$ & $\sqrt{ }$ & & $\sqrt{ }$ & \\
\hline 5. & $\begin{array}{l}\text { Can students solve problems } \\
\text { constructively? }\end{array}$ & $\sqrt{ }$ & & $\sqrt{ }$ & \\
\hline 6. & $\begin{array}{l}\text { Do students and teacher evaluate } \\
\text { students progress? }\end{array}$ & $\sqrt{ }$ & & $\sqrt{ }$ & \\
\hline
\end{tabular}

Table 8. Observation Sheet II Cycle I and Cycle II

\begin{tabular}{|l|l|l|l|l|l|}
\hline \multirow{2}{*}{ Description } & \multicolumn{3}{|l|}{ Cycle I } & \multicolumn{2}{|l|}{ Cycle II } \\
\cline { 3 - 6 } & & Yes & No & Yes & No \\
\hline & 1. The teacher comes to classroom on time & $\sqrt{ }$ & & $\sqrt{ }$ & \\
\hline
\end{tabular}

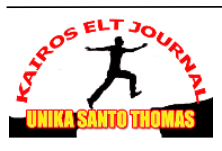




\begin{tabular}{|c|c|c|c|}
\hline $\begin{array}{l}\mathrm{T} \\
\mathrm{E} \\
\mathrm{A} \\
\mathrm{C} \\
\mathrm{H} \\
\mathrm{E} \\
\mathrm{R}\end{array}$ & $\begin{array}{l}\text { 2. The teacher greets the students } \\
\text { 3. The teacher does brainstorming to } \\
\text { introduce the topic } \\
\text { 4. The teacher explain the materials } \\
\text { 5. The teacher response the students' } \\
\text { questions and give topicchance to all } \\
\text { students to ask the topic } \\
\text { 6. The teacher uses media in presenting the } \\
\text { material } \\
\text { 7. The teacherbmotivates the students in } \\
\text { learning } \\
\text { 8. The teacher gives a chance to the } \\
\text { students to ask about the material } \\
\text { 9. The teacher concludess the lesson } \\
\text { 10. The teacher leaves the class on time }\end{array}$ & $\begin{array}{l}\sqrt{ } \\
\sqrt{ }\end{array}$ & $\begin{array}{l}\sqrt{ } \\
\sqrt{ } \\
\sqrt{ } \\
\sqrt{ }\end{array}$ \\
\hline $\begin{array}{l}S \\
\mathrm{~T} \\
\mathrm{U} \\
\mathrm{D} \\
\mathrm{E} \\
\mathrm{N} \\
\mathrm{T}\end{array}$ & $\begin{array}{l}\text { 1. The students pay atttention to the } \\
\text { teacher's explanation } \\
\text { 2. The students give participant during the } \\
\text { teachinglearning process } \\
\text { 3. The students ask the teacher about the } \\
\text { unclear lesson } \\
\text { 4. The students are given the best by the } \\
\text { teacher }\end{array}$ & $\sqrt{ }$ & $\begin{array}{l}\sqrt{ } \\
\sqrt{ }\end{array}$ \\
\hline $\begin{array}{l}\text { S } \\
\mathrm{I} \\
\mathrm{T} \\
\mathrm{U} \\
\mathrm{A} \\
\mathrm{T} \\
\mathrm{I} \\
\mathrm{O} \\
\mathrm{N}\end{array}$ & $\begin{array}{l}\text { 1. The classroom is far from crowd } \\
\text { 2. The classroom is clear and fresh } \\
\text { 3. The classroom is comfortable } \\
\text { 4. The classroom has good feedback } \\
\text { between students or students and teacher }\end{array}$ & $\begin{array}{l}\sqrt{ } \\
\sqrt{ } \\
\sqrt{ } \\
\sqrt{ }\end{array}$ & $\begin{array}{l}\sqrt{ } \\
\sqrt{ } \\
\sqrt{ } \\
\sqrt{ }\end{array}$ \\
\hline
\end{tabular}

\section{Field Notes}

In this study, the writer also used the field notes as the instrument of collecting the data during the teaching and learning process. The writer observed the Puzzle the students' improvement in vocabulary mastery after implementing this technique. Finally, the writer ended the class by thanking the students. The writer closed the meeting by praying and saying goodbye to the students.

\section{Questionnaire}

The questionnaire was conducted after both of cycles done. From the questionnaire the writer found out the syudents' response which were tought by apllying Word Search Puzzle wheter it was apropriate with improvement of students' vocabulary mastery or not. The questionnaire was used to know students' response toward the technique that writer applied. The questionnaire was consisted of 4 items namely Strong Agree, Agree, Strongly Disagree, Disagree. The students' response can be seen as follows:

Table 9. Questionnaire of Students' Response on Word Search Puzzle 
KAIROS ELT JOURNAL, Vol. 2, No. 1, April 2018

Copyright@2018, ISSN: 2580-4278

\begin{tabular}{|c|c|c|c|c|c|c|}
\hline No & Criteria & $\begin{array}{l}\text { Strongly } \\
\text { Agree }\end{array}$ & Agree & $\begin{array}{l}\text { Strongly } \\
\text { Disagree }\end{array}$ & $\begin{array}{l}\text { Dis } \\
\text { agree }\end{array}$ & $\begin{array}{l}\text { Total } \\
\text { Students }\end{array}$ \\
\hline 1. & $\begin{array}{l}\text { Saya senang belajar kosakata } \\
\text { dengan menggunakan Word } \\
\text { Search Puzzle }\end{array}$ & 23 & 9 & - & - & \\
\hline 2. & $\begin{array}{l}\text { Penerapan Word Search Puzzle } \\
\text { dapat meningkatkan kosakata } \\
\text { saya }\end{array}$ & 20 & 12 & - & - & \\
\hline 3. & $\begin{array}{l}\text { Kegiatan belajar mengajar } \\
\text { dengan menggunakan Word } \\
\text { Search Puzzle menyenangkan }\end{array}$ & 22 & 10 & - & - & \\
\hline 4. & $\begin{array}{l}\text { Word Search Puzzle membantu } \\
\text { saya memahami kosakata } \\
\text { dengan lebih mudah }\end{array}$ & 18 & 14 & - & - & 32 \\
\hline \multirow[t]{3}{*}{5.} & $\begin{array}{l}\text { Saya termotivasi } \text { belajar } \\
\text { kosakata bahasa Inggris dengan } \\
\text { menggunakan Word Search } \\
\text { Puzzle. }\end{array}$ & 22 & 10 & - & - & \\
\hline & Total & 105 & 55 & - & - & 160 \\
\hline & Percentage & $66 \%$ & $34 \%$ & - & - & $100 \%$ \\
\hline
\end{tabular}

From the table 7, it can be seen that students' responses were agree on this technoque. From the total answer, there are 105 (66\%) students strongly agree and 55(34\%) students agree with aplication Word Search Puzzle. There were no student who choose strongly disagree and disagree. Those percentage showed that Word Search Puzzle could be used in teaching learning vocabulary. Therefore, based on the result of questionnaire above, the writer could conclude that all the students (32) agreed that the application of Word Search Puzzle it could improve students' vocabulary mastery.

\section{Discussion}

Word Search Puzzle was applied to improve students' vocabulary mastery at the seventh grade students of SMP Trisakti 1 Medan. As the collaborator, the English teacher collaborated with the writer. They concluded that the use of Word Search Puzzle could be effective way to help the students in improving their vocabulary mastery. It was shown in histogram 4.4, in which mean score of each test improved. The mean score of pre-test was 52,89 , formative test was 81,81 , and the post-test was 87,10 . Those scores showed that the second cycle was better than the first cyclee. And the increasing point from pre-test to post-test was 27.

The improvement can be also seen from the percentage of students who got score $\geq 70$. In pre-test, there are $5(15,63 \%)$ students who got score $\geq 70$, in formative ttest, there are 31 $(96,87 \%)$ students who got score $\geq 70$. And then, there are $27(78,13 \%)$ students who got score $\geq 70$ in posr-test. Besides that, the improvement can be seen in the observation sheet, field notes, and questionnaire. Most of the students were more active and anthusiastic during the process of teaching and learning that started from the first to second cycle when the technique was applied. 
Word Search Puzzle was suitable technique to improve students' vocabulary mastery because this technique gave students a change to cooperate each other in order to solve a problem. After that, the students are demanded to be more active so that they could revised, discussed and combined feedback or suggestion on paper which has function to improve students' vocabulary mastery. In this study, students were focused on the animal word search. As the result, the students' score test improved in both of cycle after being taught Word Search Puzzle and also gave good response and condition to all students in teaching leraning.

\section{CONCLUSIONS} as follows:

After analyzing and presenting data in the previous chapter, the writer gives conclusions

1. Word Search Puzzle can improve students' vocabulary mastery. The students' mean score from pre-test to post-test. The students' mean score of pre-test is 52,89 , formative test is 81,81 and post-test 87,10 . Meanwhile, the students score percentage who passed (Minimum Mastery Criteria (Kriteria Ketuntasan Minimal(KKM) ) from pre-test is $15,63 \%$, the formative test is $96,87 \%$ and post-test is $78,13 \%$. The students' score and percentage continuously increased each test. Therefore, it is concluded that Word Search Puzzle can improve students' vocabulary mastery successfully.

2. The students' responsee were very good. They agreed that the aplication of Word Search Puzzle could improve their vocabulary mastery. The analysis of qualitative data showed that the students were more active and anthusiastic in leraning vocabulary after Word Search Puzzle was aplied.

\section{BIBLIOGRAPHY}

Allen, French Virginia. 1983. Techniques in Teaching Vocabulary. England: Oxford University Press.

Best, W. J. and Khan, V. J. 2002. Research in Education. New Delhi: Prentice-Hall.

Burns, A. 2010. Doing Action Research in English Language Teaching: A Guide for Practitioners. New York: Roudledge.

A. 1999. Collaborative Action Research for English Language Teachers. Cambridge: Cambridge University Press.

Celce, Murcia and Olshtain. 2000. Discourseand Context in Language Teaching. Cambridge: Cambridge University Press.

Furtwengler, C. B. 1992. How to Observe Cooperative Learning Classroom. Canberra: Educational Leadership.

Harmer, J. 1991. The Practice of English Language Teaching. Harlow: Longman Group.

Hatch, E and Brown, C. 1995. Vocabulary, Semantic and Language Education. New York: Cambridge University Press.

Heinich, R. 1996. Instructional Media and Technologies for Learning. Indianapolis: Cambridge University Press.

Husni, Mubarok. 2015. Research in Language Education. Jogjakarta: Lingkar Media.

Kamil, M and Hiebert, E. 2005. Teaching and Learning Vocabulary. Mahwah: Lawrence Erlbaum Associates. 
KAIROS ELT JOURNAL, Vol. 2, No. 1, April 2018

Copyright $\odot 2018$, ISSN: 2580-4278

Permatasari, W. M. Improving the Eighth Grade Students' Vocabulary Achievement by Using Crossword Puzzles at MTsN Arjasa Jember. An Unpublished Sarjana's Thesis, Faculty of Teacher Training and Education: Jember University.

Richard, J.C and Renandya, W. A. 2002. Methodology in Language Teaching, Cambridge: Cambridge University Press.

Richard, J.C and Rodgers, Theodore S. 1986. Approches and Method in Language Teaching. Cambridge: Cambridge University Press.

Rosi, Rosita. 2015. Teaching English by Using Puzzle to Improve Students' Vocabulary Mastery (An Experimental Study on the Fifth Grade Students' at SDN Tanjung Laya III) An Unpublished Sarjana's Thesis, faculty of Teacher Training and Education: STKIP Siliwangi Bandung.

Utami, Y. S. 2014. Improving Students' Vocabulary Mastery Using Crossword Puzzles for Grade VII of SMP Srandakan in the Academic Year of 2013/2014. An Unpublished Sarjana's Thesis, Faculty of Teacher Training and Education: Universitas Negeri Yogyakarta.

Vacca, Richard and Vacca Anne. 1999. Content Area Reading Literacy and Learning Across the Curriculum. Cambridge: Wesley Educational Publisher Inc. 